\title{
The Exam Cheating among Tunisian Students of the Higher Institute of Sport and Physical Education of Sfax
}

\author{
Jaouhar Hamani ${ }^{1}$, Nasr Chalghaf ${ }^{2}$, Habib Maaloul ${ }^{1}$, Fairouz Azaiez ${ }^{1,2}$ \\ 1- Higher institute of Sport and Physical Education of Sfax (Tunisia) \\ 2- Studies Group of Development and Social Environment (Faculty of Letters and Social Sciences of Sfax.)
}

\begin{abstract}
The phenomenon of exam cheating was a big problem to the nation's education system., Oduwaiye (2005);Jega (2006), Ijaiya (2004); Joshua (2008); Olatunbosun (2009); Omonijo \& Fadugba (2011).This phenomenon, which gangrenes the universities and affects all student profiles, had an extent and becomes a global problem in the world. Tunisia is hardly affected by cheating on exams. Our research is focused on the study of the phenomenon of cheating on scholar exams at the Tunisian University. 365 students from the Higher Institute of Sport and Physical Education of Sfax (Tunisia) with mean age 20.9 \pm 1.4 years for boys and $20.5 \pm$ 1.2 years for girls participated in the realization of this study. Our results about the link between the choice of the undergraduate section and cheating chowed a negative results $(p=0.676, d d l=4)$. Also our results showed that women cheat as much as men (49.8\% against 50.2\%)) and that cheating does not depend on gender( $p=$ $0.278, d d l=1)$. Contrariwise, the relationship between the university curriculum and cheating was significant at $(p=0.007, d d l=2)$.
\end{abstract}

Keywords: Exam Cheating, academic curriculum; Gender

\section{Introduction}

The degradation of student's environment is likely to promote the emergence of cheating in the university exams. The Exam Cheating is a complex phenomenon that is neither confined to a specific geographical hemisphere, nor to any cultural exclusivity. Many reviewed studies on cheating in the west college areas (Davis, Drinan \& Gallant., 2009; Anderman \& Murdock., 2007). Nowadays, cheating managed to reach all areas and takes several names depending on the area in question. We talk about fraud or doping in sport, nepotism, corruption, embezzlement or fraud in the business or administration (Teixeira \& Rocha., 2010). Tunisia has been hardly affected by cheating on exams. The cheating phenomenon has become too entrenched in manners so it is spread everywhere and involving our scale of socio-cultural values. The Institutions, particularly in higher education, have triggered the alarm bells for governing bodies, involved emergency and carry out a reform of the education system. Only in Tunisia, no study has addressed the cheating to estimate the actual size and try to find adequate solutions to this phenomenon. Indeed, the Tunisian universities seem to be spared.

The objective of this exploratory study is to try to understand the vulnerability of some students of the High Institute of Sport and Physical Education of Sfax (Tunisia) to the Exam cheating phenomenon. In addition, to identify the individual and environmental reasons behind cheating.

\section{Exam Cheating}

In the subject that interests us here which is the fraud in the university exams, it is important to note that according to Gillis., (2007), cheating has as cause, the cultural context, both in academic area and outside. Thus, in the same vein, Callahan (2004) estimates that fraud could be quite important in societies where failures are severely punished and rewarded highly successful ones. In this regard, cheating is defined by Teixeira and Rocha (2010) as "acts which cover areas identified as illegal, unethical, immoral or that go against the rules either in the course or in the universities "and believe that countries where cheating is most prevalent are highly corrupt countries at different levels of society. In addition, and in schools, cheating includes any unfair means used to get answers to the questions in an examination test or work. It is also called academic dishonesty. It covers cheating, forgery, identity theft, plagiarism and counterfeiting (Canadian Council on Learning, 2010). Around the world, cheating at the university and elsewhere, has become commonplace. Indeed, there is a large number of students, without remorse, try to improve their grades or to avoid failure by defying the rules (Szabo \& Underwood., 2004). This phenomenon has attracted the attention of many researchers from different nations. American research has shown, for this purpose, a majority of students, estimated at $70 \%$, are engaged in "fraudulent" practices more or less intense in their academic careers (Whitley., 1998; McCabe., Trevino \& Butterfield., 2001). 
In this regard, Nicole Perreault (2007), moved toward plagiarism and academic cheating using the new telecommunication technologies to Canadian students. Similarly in Cameroon, MMboe (2010) conducted a recent research more on the psychological analysis of students from the University of Yaounde 1, facing the phenomenon of cheating. In addition, two Portuguese researchers, Teixeira \& Rocha .,(2010), worked hardly by conducting a comprehensive study on an international scale (7213 questionnaires across 21 countries).

\section{The Cheating Triggers}

Several researches have been carried out and revealed that various reasons are behind students cheating on exams. They consider that the workload is too heavy, the organization of examinations is inadequate and also the transmission of knowledge is maladjusted (Guibert., \& Michaut., 2009) when they seek to improve their grades or to avoid failure by cheating at exams (Szabo \& Underwood., 2004). In addition, and as the evaluation method produces winners and losers, they try to win or in other words, pass exams even with cheating (Chiesl., 2007). This seems easy for them because they feel that the risk of detection is often minimal (Szabo \& Underwood., 2004) and even if it will arrive, the penalty is low (Etter., Cramer \& Finn., 2006), since the seriousness of cheating is underestimated in some institutions that can encourage students to cheat (McCabe., 2005).Furthermore, these students are not fully aware of the penalties and therefore can violate the academic rules (Ma, Lu, Turner \& Wan., 2007). It is in the context of academic dishonesty is tolerated (or perceived) in a facility that students can be particularly prone to cheat. Moreover, $41 \%$ of faculty teachers in the United States and Canada, simply do not care academic dishonesty (McCabe., 2005). Other triggers can bring students to cheat. Indeed, under the effect of stress or panic, the candidate loses his means and no longer able to answer some questions, then succumbs to the temptation to cheat (Teixeira \& Rocha., 2010).Much more, , in some institutions, the severity of cheating is underestimated which can encourage his followers to cheat (McCabe., 2005), and even exclude their misconduct under cheating or trivializing the problem .Similarly, an adequate control of high technology such as computers or mobile phones facilitates the accomplishment of fraud (Arhin., 2009), especially the internet is full of research and publications for fraudsters with "copy-paste "to appropriate the work of others, (Gibelman., Gelman., and Fast., 1999). Also, a carefree and passive attitude of parents regarding academic dishonesty and their desire to satisfy their descendants stimulates students to cheat (Common Sense Media, 2009).

\section{Cheater's Profile}

Whatever the field, who does not respect the moral and afraid to fail, is guilty of unlawful acts to conceal his inability to complete the required task (Szabo \& Underwood., 2004). This transgression of the moral and ethical's social values in the university environment that comes from discomfort created by the review period at students. The cheater realizes later on his lack of commitment to overcome obstacles. Thus, he will devise schemes and use illegal actions either by denial of failure and seeks to ensure its average examination or by obsessional behavior to get a better grade (Guibert \& Michaut., 2009). According to the researchers, there are few students who start cheating in entering university. On the contrary, those who have a lot cheated in college or in high school, will cheat much more at the university "The intensity of examination fraud is highly dependent on the experience already gained in this field" (Guibert \& Michaut., 2009). Moreover, this phenomenon affects all social classes (Guibert \& Michaut., 2009) and all levels of university education (Teixeira \& Rocha., 2010). The latter revealed, on the one hand that "students who cheat the most are those in the year end of cycle" for fear of missing their target as close to the goal, while "the best and brightest students less likely to cheat" For fear of losing everything by being taken. Moreover, Guibert \& Michaut (2009) stated that the weaker students cheat less because they have lost hope of benefit.

\section{Environmental Influence}

It is the ability of the environment to perform an action or produce positive or negative effects on academic performance of the child. According to Doron \& Parot (1990), the interaction is considered as a set of joint actions carried out by members of a group, built around a defined purpose. From these definitions, we can infer a set of actions between environment and the scholar oriented child is the interaction between the child and his entourage around his academic success (Ronald \& Calixte., 2008).

\section{The Parents Positions}

Infact when schools have a place for parents and encourage them to get involved in various committees and activities, school climate will be affected (Born \& al., 2006). According to Piaget (1926), children learn best when they interact with their environment. Parents and teachers are two key elements of this environment. We must find ways to ensure that these stakeholders interact effectively for positive results on student achievement (Boutin., Méchaly \& al., 2009; Battle-Bailey., 2004; Van Voorhis., 2003). Nowadays, parents have become very concerned about the future of their offspring, by providing them an overdose of attention. However, this may 
cause excessive pressure, which gradually can become a major cause of the drift of the child to the school cheating. Also this by repeating endlessly to them that the child should interest to succeed, and the success and diplomas are capital. Therefore this outlook can sometimes encourage children to cheat to get good results and meet the desires of their parents who explained to them that the child who cheats is not necessarily a bad student but he is a student who gets better by cheating. (Pech., 2011).

\section{Gender and Cheating}

Gender differences are common in everyday life, and an area of research that showed these differences about cheating on exams in academia, especially in academic institutions. Academic cheating has been examined in many studies, but few have considered the importance of gender as a variable in cheating (Hendershott., Drinan \& Cross., 1999). Previous research has indicated that the strongest and most often reported demographic correlate of cheating is sex "(Mustaine \& Tewksbury., 2005). Previous studies have produced mixed results regarding gender differences in cheating in the academic field. Whitley., BichlmeierNelson, \& Jones (1999), found that men and women were almost equal in their desire to cheat, (Mustaine \& Tewksbury., 2005) found that women were less likely to cheat than men. Robinson ., Amburgey \& al., (2004) found that gender showed that women have a positive consistent patterns learned from cheating. Other research has examined whether men or women are more likely to be seen in different situations found that women are more likely to receive help than men (Eagly \& Crowley, 1986), but relatively little research has been done so far to determine if the help to the a member of the same sex or the opposite one was more likely in cheating. At present, little research on the differences in compliance for mixed combinations against same sex has been conducted that is easily accessible. It is also important to note that studies of cheating, including those related to gender as a factor, had no experimental studies but they were in a survey or questionnaire form.

\section{Methods}

Our research focused on the study of the representations of exam cheating among students from the Higher Institute of Sport and Physical Education of Sfax (Tunisia) in 2012. 365 students with mean age 20.9 \pm 1.4 years for boys and $20.5 \pm 1.2$ years for girls participated in the realization of this study. The population was proportionally distributed according to the levels of study, 137 respondents were registered in the first year of the Basic Degree in Physical Education with 61 men and 76 women, 130 in the second year consisted of 68 men and 62 women and 98 in the third year counting 47 men and 51 women. We used the questionnaire as a tool for collecting data in order to measure the propensity for cheating. In our survey we used two types of questions: closed-ended questions and multiple choice questions. The questionnaire consists of two parts:

The first part containing information of student characteristics (age, gender, educational level), which will allow us to see in our analysis the influence of these factors on the behavior of the students face to cheating phenomenon. The second part will consist of the independent variables are presented in the format of an ordinal scale type Likert ranging from 1 (never) to 5 (always). The Statistical analysis of the questionnaire was carried out on a microcomputer. The statistical data were treated by means of chi-square and all informations were collected through the Excel.

\section{Results}

\section{Relationship between the section of the Bachelor and cheating}

The statistical data used, determining the relationship between the choice of the section of undergraduate and cheating, contain negative results $(\mathrm{p}=0.676, \mathrm{ddl}=4)$ which reflects the difference between cheater and not cheater among the Sport's section (28.16\% against $20 \%)$ or another sector $(72.13 \%$ against $79.34 \%$ ) is insignificant. This made the section of bachelor has no influence on the behavior of the student face to cheating phenomenon (table 1).

Table 1: Relationship between the section of the Bachelor and cheating

\begin{tabular}{|c|c|c|}
\hline & \multicolumn{2}{|c|}{ What is your section? } \\
\hline & Non Cheaters & Cheaters \\
\hline Letters & $47(39,17 \%)$ & $82(33,47 \%)$ \\
\hline Maths & $9(7,5 \%)$ & $14(5,71 \%)$ \\
\hline Economic & $17(14,17 \%)$ & $39(15,92 \%)$ \\
\hline Technics & $4(3,33 \%)$ & $11(4,49 \%)$ \\
\hline Sport & $24(20 \%)$ & $69(28,16 \%)$ \\
\hline Computer Science & $6(5 \%)$ & $9(3,67 \%)$ \\
\hline Experimental Science & $13(10,83 \%)$ & $21(8,57 \%)$ \\
\hline
\end{tabular}

Chi Square $(6 d d l)=4 ; p=0,676$ 


\section{Relationship between the university curriculum and cheating}

Our results reveal that students "cheaters" have much less ambitions those students "non cheaters». The first ones opt mainly for study along 3 years or 5 years $(42.04 \%$ against $33.33 \%)$ and much less planning in doctoral studies $(17.14 \%$ against $31.67 \%)$. This difference choice of the university curriculum between cheaters and non-cheaters is significant at $(\mathrm{p}=0.007, \mathrm{ddl}=2)$ and this is due to their ambition which limit the propensity for cheating (Table 2).

Table 2: Relationship between the university curriculum and cheating

\begin{tabular}{|c|c|c|}
\hline Academic Curriculum & \multicolumn{2}{|c|}{ You May do ? } \\
\hline & Non Cheaters & Cheaters \\
\hline 3 study years (License) & $40(33,33 \%)$ & $103(42,04 \%)$ \\
\hline 5 study years (Master) & $42(35 \%)$ & $100(40,82 \%)$ \\
\hline More than 5 study years (Doctorate) & $38(31,67 \%)$ & $42(17,14 \%)$ \\
\hline
\end{tabular}

Chi Square $(2 \mathrm{ddl})=10,01 ; p=0,007$

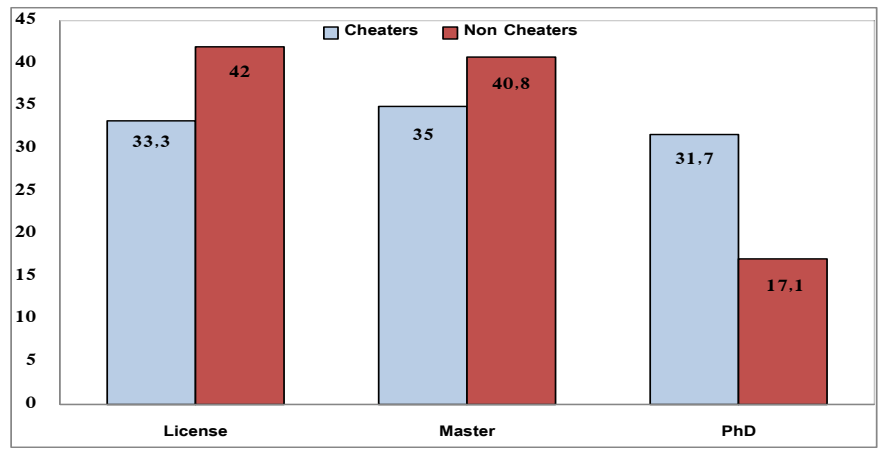

Fig 2: Relationship between the university curriculum and cheating (\%)

\section{Relationship between gender and exam cheating}

The results show that women cheat as much as men (49.8\% against 50.2\%) and that exam cheating does not depend on gender $(\mathrm{p}=0.278, \mathrm{ddl}=1)$, which means that the gender of the student does not report to be "cheater" or "not cheater"(Table 3).

Table 3: Relationship between gender and exam cheating

\begin{tabular}{|c|c|c|}
\hline & \multicolumn{2}{|c|}{ Gender } \\
\hline Male & $53(44,17 \%)$ & $123(50,2 \%)$ \\
\hline Female & $67(55,83 \%)$ & $122(49,8 \%)$ \\
\hline
\end{tabular}

Chi Square $(1 \mathrm{ddl})=1,18 ; p=0,278$

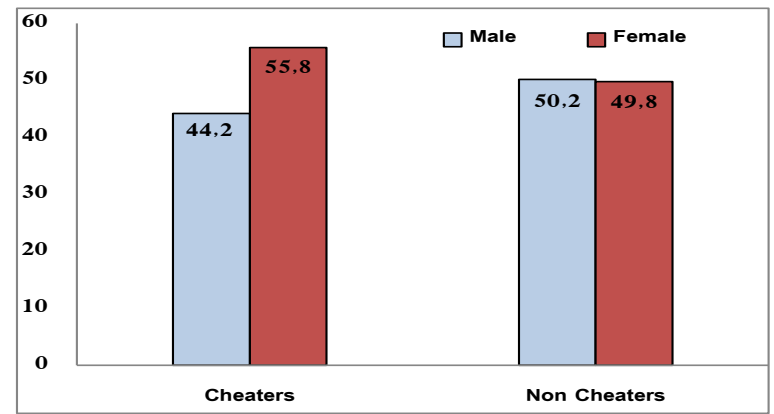

Fig 3: Relationship between gender and exam cheating (\%) 


\section{Discussion}

Academic cheating and deception are both prohibited and reprehensible acts. In research done by Teixeira \& Rocha (2010), a highlighting of the paradox observed about students. On the one hand, the majority of students say that they are against cheating and it is not ethical behavior in relation to social life. On the other hand, they admit having practiced from time to time. This paradox is also found in our study. Indeed, more than $70 \%$ of students of the Higher Institute of Sport and Physical Education of Sfax (Tunisia) admit to having committed at least once a fraudulent act in exams and most of them recognize that cheating is not only a noncompliance with the rules to get a result, but it is also an immoral behavior. This proportion (70\%) seems high but not exceptional which is consistent with the results found by Pech., (2011); Teixeira \& Rocha., (2010), with similar percentages and even higher.

In addiction, a minority of students "cheaters" in the Higher Institute of Sport and Physical Education of Sfax (Tunisia) feel some shame at having achieved results without effort, a third party believes that the success without merit is not very pleasant but the majority believes smarter and appreciate the intellectual dishonesty much more they believe that the key is to ensure or improve the results. By cons, the non cheater students who got their results by merit, compared to cheaters ones who have achieved better results, they feel a sense of injustice and frustration., (Crahay., 2007).

The results identified upstream, in our investigation show that factors such as gender, the tray section and grade level of the student are not decisive in the propensity for academic cheating phenomenon. These results support our conclusions regarding the influence of gender and grade level of the student about exam cheating.

The study of the archives of the students at the Higher Institute of Sport and Physical Education of Sfax (Tunisia) who were seized to the council of discipline from 2004 to 2012 found that there was no significant difference in proportion between "cheaters men" and "cheaters women". Contrariwise, Anugwom, Omonijo \& Fadugba (2011), concluded that male students undertake science programs than their female counterparts. Hence, they could be more involved in exam cheating than females. It also shows that students who were seized to the council of discipline are mostly students of the first and second year at the university. This confirms that more we advance in studies, less we cheat., Antonmattei \& al.,(2011). This small number of cheaters in the third grade, fourth grade and in the first year of master is explained by the fact that the "non - cheaters" are more ambitious and they are the ones that will end up in the higher levels. Unfortunately, our students learn the sole purpose of being evaluated. While, students seem to be indifferent to knowledge. Their goal is to graduate with less effort, amplified by a logical system of credits and points, which confirms their eyes that everything is sold and bought everything., (Mazodier \& al., 2012).In this case, and in order to prevent from exam cheating, some authors (Teixeira and Rocha., 2010) advocate the use of less anxiety and less stressful strategies that would be a good long-term solution.

\section{Conclusion}

Our study aims to explore the propensity of the exam cheating among the students of the Higher Institute of Sport and Physical Education of Sfax (Tunisia). Although in the student handbook of the institution internal rules appears the studies sanction, that cheating and immorality have become relatively common. In our study, we found that $70 \%$ of students have cheated at least once during their university studies. Also gender and the bachelor section have no influence on the cheating behavior of the student. By cons, students who have obtained a bachelor's degree and good average considering to study in masters or doctoral are less affected by cheating.

\section{References}

[1]. Oduwaiye, R. O. (2005)."Students' perception of factors and solutions to examination malpractices in Nigeria Universities: A case study of University of Ilorin". Ilorin Journal of Education. Volume 24.

[2]. Jega, A. M. ( 2006). "Examination Malpractice: Concept, causes, Consequences and Remedies". Education for Today, 6(2), pp. 5972.

[3]. Ijaiya, N. Y. S. (2004). "Agents of Examination Malpractices in Nigerian Public Examinations: The Strongest Links". Publication of the National Association of Educational Researchers \& Evaluators, 5 (1): 55-62.

[4]. Joshua, M. T. (2008). Examination malpractices. The Monster in our Midst. A paper presented at Capacity Building Workshops for Science and English Language Teachers in Akwa Ibom State, Nigeria. August 6th.

[5]. Olatunbosun, J. B.( 2009). "Examination Malpractice in Secondary Schools in Nigeria: What Sustains it? Examination malpractice in Nigeria what sustains it?" European Journal of Educational Studies 1 (3), pp. 6-7.

[6]. Omonijo, D. O. \& Fadugba, O. (2011). Parental Influence in Escalation of Examination Malpractices in Nigeria. European Journal of Social sciences. 19 (2): 297-307.

[7]. Davis, S.F., Drinan, P.F. \& Gallant, T.B. (2009). Cheating in school: What We Know and What We Can Do. Chichester, West Sussex, UK: Wiley-Blackwell.

[8]. Anderman, E. M. \& Murdock, T. B. (2007). The psychology of academic cheating. In E. M. Anderman \& T. B. Murdock (Eds.), Psychology of academic cheating (pp. 1-5). Burlington, MA: Elsevier.

[9]. Teixeira, A., \& Rocha, M. (2010). Cheating by economics and business undergraduate students: an exploratory international assessment. Higher Education, 59(6), p. 663-701. 
[10]. Gillis, A.(2007).Qui trompent-ils réellement?,Affaires $\quad$ Universitaires. $\quad$ Consulté $\quad$ le $23 \quad$ juin $2007 \quad$ sur http://www.affairesuniversitaires.ca/Francais/issues/2007/avril.

[11]. Callahan, D. (2004). The Cheating Culture: Why More Americans are doing Wrong to Get Ahead. New York: Harcourt Publishers.

[12]. Conseil Canadien sur l'Apprentissage. (2010). Mensonge et tricherie : prendre en main la croissance de la malhonnêteté scolaire.

[13]. Szabo, A., \& Underwood, J. (2004). Cybercheats: Is information and communication technology fuelling academic dishonesty? Active Learning in Higher Education. Vol. 5, no 2, p. 180-199.

[14]. Whitley, Bernard. E. Jr. (1998), "Factors Associated with Cheating Among College Students: A Review," Research in Higher Education, 39 (3), 235-274.

[15]. McCabe, D.L., Trevino, L.K., \& Butterfield, K.D. (2001). Cheating in Academic Institutions: A Decade of Re-search. Ethics and Behavior. Vol. 11, n³, p. 219-231.

[16]. Perreault, N. (2007). Plagiarism and Other Types of Electronic Cheating - creating solutions to a new reality. Published in Profweb, February 2nd 2007, 16 pages.

[17]. Mboe, G.G. (2010). Fraude et tricherie en milieu universitaire. Conférence le 27 mai 2010, Université de Yaoundé I (CAMEROUN).

[18]. Guibert, P., \& Michaut, C. (2009). Les facteurs individuels et contextuels de la fraude aux examens universitaires. p. 43-52. Revue française de pédagogie, décembre 2009, éditée par l'INRP en juin 2010.

[19]. Chiesl, N., (2007). Pragmatic methods to reduce dishonesty in web-based courses. The Quarterly Review of Distance Education. Vol. 8 , no 3, p. 203-211.

[20]. Etter, S., Cramer, J.J., \& Finn, S. (2006). Origins of academic dishonesty: Ethical orientations and personality factors associated with attitudes about cheating with information technology. Journal of Research on Technology in Education. Vol. 39, no 2, p. $133-155$.

[21]. McCabe, D.L. (2005). Cheating among college and university students: A North American perspective. International Journal of Educational Integrity. Vol. 1, no 1, p. 1-11.

[22]. Ma, H., Lu, E.Y., Turner, S., \& Wan, G., (2007). An empirical investigation of digital cheating and plagiarism among middle school students. American Secondary Education. Vol. 35, no 2, p. 69-82.

[23]. Arhin, A. O. (2009).A pilot study of nursing student's perceptions of academic dishonesty: A generation Y perspective. ABNF Journal, 20(1), 17-21.

[24]. Gibelman, M., Gelman, S. R., \& Fast, J. (1999). The downside of cyberspace: Cheating made easy. Journal of Social Work Education, 35(3), 367-376.

[25]. Common Sense Media.(2009). Hi-Tech Cheating:Cell Phones and Cheating in Schools, A National Poll. Accessed March $24,2009$.

[26]. DORON R. et PAROT F. (1990) Dictionnaire de Psychologie. Paris. PUF (4ème édition 2003 ; traduit en plusieurs langues).

[27]. Ronald, J. J. \& Calixte, J. (2008). Milieu familial et réussite scolaire « Du rôle des interactions parents-adolescents axées sur l'école dans la réussite scolaire de l'adolescent haïtien vivant en milieu défavorisé ». Faculté des Sciences Humaines. Université d'Etat d'Haïti (UEH).

[28]. Born, M., Lafontaine, D., \& all. (2006). Prévenir le décrochage scolaire des jeunes lors de la transition primaire-secondaire. Université de Liège. Responsables du projet : Born, M., et Lafontaine, D., Chercheurs : Poncelet, D., Crochelet, F., et Bernard, S., Recherche $\mathrm{n}^{\circ} 117 / 05$, Rapport final.

[29]. Piaget, J. (1926). La représentation du monde chez l'enfant. Paris, PUF.

[30]. Boutin, N., Méchaly, L., \& all. (2009). Conseil supérieur de l'éducation. Pour soutenir une réflexion sur les devoirs à l'école primaire. Québec, dépôt légal mars 2010.

[31]. Battle-Bailey, L. (2004). Interactive Homework for Increasing Parent Involvement and Student Reading Achievement. Childhood Education, vol. 81, no. 1, fall, p. 36.

[32]. Van Voorhis, F. (2003). Interactive Homework in Middle School: Effects on Family Involvement and Science Achievement. The Journal of Educational Research, vol. 96, no. 6, July, p. 323-338.

[33]. Pech, M-E. (2011). L'école de la triche. Paris, L'éditeur, Octobre 2011, 250 pages.

[34]. Hendershott, A., Drinan, P. F., \& Cross, M. (1999). Gender and academic integrity. Journal of College Student Development, 40, 345-354.

[35]. Mustaine, E. E. and Tewksbury, R. A.(2005). Southern College Students' Cheating Behaviors: An Examination of Problem Behavior Correlates. Deviant Behavior, 26(5): 439-461.

[36]. Whitley, Jr., B., Bichlmeier Nelson, A., \& Jones, C. J. (1999). Gender differences in cheating attitudes and classroom cheating behavior: A meta-analysis. Sex Roles, 41, 657-680.

[37]. Robinson, E., Amburgey, R., Swank, E. \& Faulkner, C. (2004). Test cheating in a rural college: Studying the importance of individual and situational factors. College Student Journal, 38(3), 380-395.

[38]. Eagly, A.H., \& Crowley, M. (1986). Gender and helping behavior: A meta-analytic review of the social psychological literature. Psychological Bulletin, 100(3), 283-308.

[39]. Anugwom, E. E; Omonijo, D. O. \& Fadugba O. A (2011). A Review of Gender Performance of Graduating Students in a Private Christian Mission University in Nigeria between 2008 and 2010. International Journal of Gender Empowerment and Development. (10), $1 \& 2$.

[40]. Crahay, M.(2007). Peut-on lutter contre l'échec scolaire ?, Bruxelles, De Boeck Supérieur « Pédagogies en développement », 2007, 384 pages.

[41]. Mazodier, M., Blemont, P., Foucault, M., \& Kesler, S. (2012). La fraude aux examens dans l'enseignement supérieur. Rapport à Monsieur le ministre de l'Enseignement supérieur et de la Recherche - n 2012-027. Inspection générale de 1'administration de l'Éducation nationale et de la Recherche. République française.

[42]. Antonmattei, P., Fouquet, A. (2011). La Lutte contre l'absentéisme et le décrochage scolaires. Rapport de la mission permanente d'évaluation de la politique de prévention de la délinquance, p 90. 